\title{
Electroacupuncture attenuates liver and kidney oxidative stress in anesthetized rats ${ }^{1}$
}

\author{
Eletroacupuntura atenua o estresse oxidativo no fígado e no rim em ratos anestesiados
}

\author{
Agamenon Honório Silva', Lanese Medeiros FigueiredoI, Paulo Araujo Dias ${ }^{I}$, Alberico Ximenes do Prado Neto ${ }^{I I}$, Paulo Roberto \\ Leitão de Vasconcelos ${ }^{\text {III, }}$, Sérgio Botelho Guimarães ${ }^{\text {IV }}$ \\ ${ }^{I}$ Fellow Master Degree, Department of Surgery, Postgraduate Program, UFC, Ceara, Brazil. Technical procedures, acquisition and interpretation of \\ data. The article is part of a master degree dissertation (AHS).

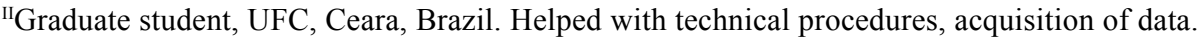

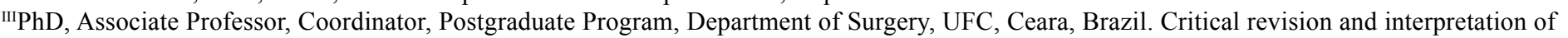 \\ data. \\ ${ }^{\mathrm{IV}} \mathrm{PhD}$, Associate Professor, Department of Surgery, Head, LABCEX, UFC, Ceara, Brazil. Tutor, conception, design, intellectual and scientific \\ content of the study, manuscript writing, statistical analysis.
}

\begin{abstract}
PURPOSE: Investigate the effects of a single electroacupuncture (EA) session at acupoints Zusanli (ST-36) and Zhongwan (CV-12) combined in regulating oxidative stress in liver and kidney in anesthetized rats.

METHODS: Eighteen healthy rats randomly assigned to 3 groups $(n=6)$ were anesthetized intraperitoneally with ketamine (90mg $\mathrm{kg}^{-1}$ body weight $)+$ xylazine $(10 \mathrm{mg} / \mathrm{kg}$ body weight): G-1: Control (anesthesia), G-2: anesthesia $+\mathrm{EA} 10 \mathrm{~Hz}$ and $10 \mathrm{~mA}, 10 \mathrm{~Hz})$ applied to right ST-36 and CV-12 acupoints for 30 minutes. G-3 was likewise treated, using a tenfold higher frequency (100 Hz). G6PDH activity, malondialdehyde (MDA) and glutathione (GSH) levels were assayed spectrophotometrically.
\end{abstract}

RESULTS: Liver MDA and GSH concentrations increased significantly in rats submitted to EA $10 \mathrm{~Hz}(\mathrm{p}<0.01)$ and EA 100Hz (p<0.001), compared with control G-1. Liver and kidney G6GPH activity decreased significantly in G-2 ( $p<0.01)$ and G-3 (p<0.001) compared with G-1 in EA100Hz rats. A similar pattern was found in kidney G6PDH activity in EA10Hz rats.

CONCLUSION: Single 30-minute EA 10/100Hz session enhances lipid peroxidation and simultaneously reduces oxidative stress in liver and kidney tissues in a rat model.

Keywords: Acupuncture. Electroacupuncture. Lipid Peroxidation. Oxidative Stress. Rats.

\section{RESUMO}

OBJETIVO: Investigar os efeitos de uma única sessão de eletroacupuntura (EA) aplicada nos acupontos Zusanli (E-36) e Zhongwan (RM-12) simultaneamente, na regulação do estresse oxidativo no fígado e rins em ratos anestesiados.

MÉTODOS: Dezoito ratos sadios, distribuídos aleatoriamente em três grupos $(\mathrm{n}=6)$, foram anestesiados com cetamina $(90 \mathrm{mg} / \mathrm{kg}$ de peso) + xilazina (10mg/kg de peso): G-1: Controle (anestesia), G-2: anestesia + EA10Hz e G-3: anestesia + EA100Hz. Os ratos do grupo G-2 foram submetidos à EA (ondas quadradas pulsadas, $10 \mathrm{~mA}, 10 \mathrm{~Hz}$ ) aplicada aos acupontos ST-36 direito e VC-12 por 30 minutos. Nos ratos do grupo G-3 utilizou-se uma freqüência dez vezes maior (100 Hz). A atividade da enzima G6PDH e as concentrações de malondialdeído (MDA) e glutationa (GSH) foram verificadas por espectrofotometria.

RESULTADOS: As concentrações hepáticas de MDA e GSH aumentaram significativamente nos ratos submetidos à EA, utilizando $10 \mathrm{~Hz}(\mathrm{p}<0,01)$ e $100 \mathrm{~Hz}(\mathrm{p}<0,001)$, comparado com o controle. A atividade de G6GPH diminuiu significativamente no G-2 ( $<<0,01)$ e G-3 ( $<<0,001)$ no fígado e no rim em comparação ao grupo G-1 em ratos tratados com $100 \mathrm{~Hz}$.

CONCLUSÃO: Uma única sessão de EA 10/100Hz por 30 minutos aumenta a peroxidação lipídica e simultaneamente reduz o estresse oxidativo no fígado e no rim de ratos sadios.

Descritores: Acupuntura. Eletroacupuntura. Peroxidação de Lipídeos. Estresse Oxidativo. Ratos. 


\section{Introduction}

Manual acupuncture (MA) is one of the main forms of treatment in traditional Chinese Medicine. It involves the use of sharp, thin needles that are inserted in the body at very specific points (acupoints). MA has been used for several millennia in oriental countries and is being increasingly accepted by practitioners and patients in the West as well ${ }^{1}$. Electroacupuncture (EA) is a modification of this technique where small electrical currents are applied to needles previously inserted in the body and appears to have more consistently reproducible results in many specific clinical and research settings ${ }^{2-4}$. EA applied to Zusanli (ST-36) acupoint reduced lipid peroxidation in experimental models of ischemia/reperfusion such as rat spinal cord ${ }^{5}$, brain ${ }^{6}$ and blood serum ${ }^{7}$ and pig heart muscle ${ }^{8}$.

Chakrabarti et al. ${ }^{9}$ investigated the effect of single, acute (7 pulses/sec., 0.75 volt) and chronic (4 pulses/sec., 0.75 volt) electroacupuncture treatment on alternate days for a period of 21 days on hepatic functions of rats. Two back acupoints along with ST-36 were used. After chronic treatment, liver microsomal lipid peroxidation value decreased significantly. Moreover, given that the manual stimulation of the acupoint ST-36 is able to attenuate renal injury induced by sepsis ${ }^{10}$, it is possible that electrical stimulation of that acupoint can alter the concentrations of MDA, an indicator of cell membrane injury, in renal tissue.

Physiological processes are regulated by enzymes. NADPH is the principal intracellular reductant and its production is mainly dependent on glucose-6-phosphate dehydrogenase. If G6PDH activity is inhibited, there is a simultaneous decrease of NADPH activity, a coenzyme that is essential for the protection against oxidative damage. The integrity of the cells as well as the entire antioxidant system rely on the adequate supply of $\mathrm{NADPH}^{11}$. Many papers have demonstrated the effects of MA and EA on ST36 acupoint in attenuating oxidative stress in different experimental diseases $^{5-9}$. Furthermore, the use of ketamine+xylazine, an anesthetic mixture often used in experimental studies may induce some degree of oxidative stress in a health animal ${ }^{12-13}$.

It has been previously shown that large amounts of endogenous opioid peptides are secreted from the adrenal glands when CV-12 acupoints are stimulated using acupuncture with $2 \mathrm{~Hz}^{14}$. When a high frequency EA $(15 \mathrm{~Hz})$ was applied to stimulate the acupoint $\mathrm{CV}-12$, multiple sources of endogenous opioid peptides were discovered ${ }^{15}$. Hence, we aimed to investigate whether the application of EA, stimulating both ST36 and CV-12 acupoints, using two different frequencies, $10 \mathrm{~Hz}$ and $100 \mathrm{~Hz}$, can modify MDA and GSH content of the liver and kidney and if there is a difference in lipid peroxidation and oxidative stress between $10 \mathrm{~Hz}$ and $100 \mathrm{~Hz}$ EA in health rodents.

\section{Methods}

Approval for experimental use of laboratory animals was obtained on Sept 19, 2007 (Protocol \#09/07) from the Ethics Committee on Animal Research (CEPA) of the Federal University of Ceara, now Ethics Committee on the Use of Animals (CEUA), in view of the Federal Law No. 11794 of October 8, 2008, http:// www.planalto.gov.br/ccivil_03/_Ato2007-2010/2008/Lei/ L11794.htm and Decree No. 6689 of July 15, 2009 that regulated the Law 11794, available at: http://www.planalto.gov.br/ccivil_03/ _Ato2007-2010/2009/Decreto/ D6899.htm. The study was designed so as to minimize the number of animals required for the experiments.

\section{Animal preparation}

Male Wistar rats weighing 280-400 g, provided by the Faculty of Medicine Small Animals Breeding Facility (Federal University of Ceara) were kept under controlled environmental conditions $\left(24^{\circ} \mathrm{C}\right.$ _relative humidity $40 \%-60 \%$, 12-hour alternate light-dark cycles, food and water ad libitum). The equivalent of the human right ST-36 and CV-12 acupoints were chosen for needling and electrical stimulation. The acupoint nomenclature used follows WHO nomenclature ${ }^{16}$. ST-36 acupoint is located $5 \mathrm{~mm}$ below the head of the fibula under the knee joint, and $2 \mathrm{~mm}$ lateral to the anterior tubercle of the tibia. Puncture of ST-36 acupoint stimulates the lateral sural cutaneous nerve, the cutaneous branch of the saphenous nerve, and deeper, the deep peroneal nerve ${ }^{17-18}$. $\mathrm{CV}-12$ acupoint is located in the anterior midline of the upper abdomen, $20 \mathrm{~mm}$ below the sternal synchondrosis. This region is innervated by the anterior cutaneous branch of the $8^{\text {th. intercostal }}$ nerve ${ }^{18}$.

\section{Materials}

Disposable stainless steel needles $(0.20 \times 30 \mathrm{~mm}, 0.5 \mathrm{~cm}$, DongBang Acupuncture Inc., Chung Nam, Korea) were used. The EL-608 electro stimulator was purchased from NKL Produtos Eletrônicos Ltda., Brusque, Santa Catarina, Brazil.

\section{Experimental groups}

Animals were anesthetized intraperitoneally with a freshprepared mixture of ketamine (90mg kg/body weight) and xylazine ( $10 \mathrm{mg} \mathrm{kg} /$ body weight). Rats were randomly assigned to 3 equal groups as follows:

* Group 1 (anesthesia) - 6 rats

* Group 2 (EA 10Hz) - 6 rats

* Group 3 (EA 100Hz) - 6 rats

Group 1 (Control) rats were anesthetized as described. Sixty minutes later, the abdomen of the rats was open and the liver and right kidneys were removed. Group 2 (EA10Hz) rats were anesthetized as described. After routine skin disinfection with $75 \%$ ethanol sterilized disposable stainless steel needles $(0.25 \mathrm{~mm} \times$ $30 \mathrm{~mm}$ ) were inserted perpendicularly as deep as 2-3 $\mathrm{mm}$ at right ST-36 and CV-12 acupoints. Electrodes were connected to both needles and to an electro stimulator (NKL EL-608); pulsed square waves, $10 \mathrm{~Hz}, 10 \mathrm{~mA}$ were applied for 30 minutes. Samples were collected 30 minutes later. Group $3(\mathrm{EA} 100 \mathrm{~Hz})$ rats were submitted to EA as Group 2. However, a tenfold greater frequency $(100 \mathrm{~Hz})$ was used. 


\section{Biochemical determinations}

Parameters determined included G6PDH activity, malondialdehyde (MDA) and glutathione (GSH) concentrations. Tissue samples were snap-frozen in liquid nitrogen and stored in glass tubes at $-70^{\circ}$ until subsequent preparation and analysis of liver and kidney homogenates. Lipid peroxidation was assayed by measuring malondialdehyde as TBA-reactive substances ${ }^{19}$. In brief, $\mathrm{H}_{3} \mathrm{PO}_{4}(1 \%, 3 \mathrm{~mL})$ and aqueous TBA solution $(0.6 \%, 3 \mathrm{~mL})$ were added to the $10 \%$ homogenate $(0.5 \mathrm{~mL})$. The assay medium was shaken and heated on a boiling-water bath for $45 \mathrm{~min}$. After cooling, $4 \mathrm{~mL}$ of $n$-butanol was added and the mixture shaken. After separation of the $n$-butanol layer by centrifugation at $1200 \mathrm{~g}$ for $15 \mathrm{~min}$, its optical density was determined in a spectrophotometer (Beckman DU 640 B; Beckman Instruments, now Beckman Coulter, Inc., Fullerton, CA, USA) with 535 and $520 \mathrm{~nm}$ as absorption wavelengths, respectively. The difference between the results of the two optical density determinations was taken as the TBA value and the amount of malondialdehyde (MDA) in the testis was calculated, comparing with MDA standards and expressed as micromoles of MDA per gram of wet tissue. GSH levels were estimated by the method of Sedlak and Lindsay ${ }^{20}$ which is based on the reaction between thiol groups and 5-5-dithiobis(2-nitrobenzoic acid) to produce a compound that absorbs light at $412 \mathrm{~nm}$. The amount of GSH was determined from a standard curve simultaneously obtained under the same conditions with various concentrations of GSH. G6PDH activities were estimated by methods described previously ${ }^{21}$. Enzyme activity was read spectrophotometrically.

\section{Data analysis}

Graphpad Prism 5.0 (GraphPad Software, San Diego California USA, www.graphpad.com) was used for computation and statistical analysis. All results were expressed as mean \pm SD. All data were tested for distribution (Kolmorogov-Smirnov test with Dallal-Wilkinson-Lilliefor P value). One-way ANOVA or Kruskal-Wallis test, as required, were performed to determine differences among groups in MDA and GSH concentrations and G6PDH activity in liver and kidney tissues. In the post hoc analysis (Tukey or Dunn), a probability value of $\mathrm{p}<0.05$ was considered to indicate statistical significance.

\section{Results}

\section{GSH Assay}

Liver GSH concentrations increased significantly in rats submitted to EA $10 \mathrm{~Hz}$ and EA $100 \mathrm{~Hz}(\mathrm{p}<0.001)$, compared with control (Figure 1). Similar increases in kidney GSH concentrations occurred in both $\mathrm{EA} 10 \mathrm{~Hz}$ and $\mathrm{EA} 100 \mathrm{~Hz}$ groups (Figure 2).
Additionally, liver and kidney GSH concentrations increased significantly in EA $100 \mathrm{~Hz}$ treated rats compared with EA10Hz group.

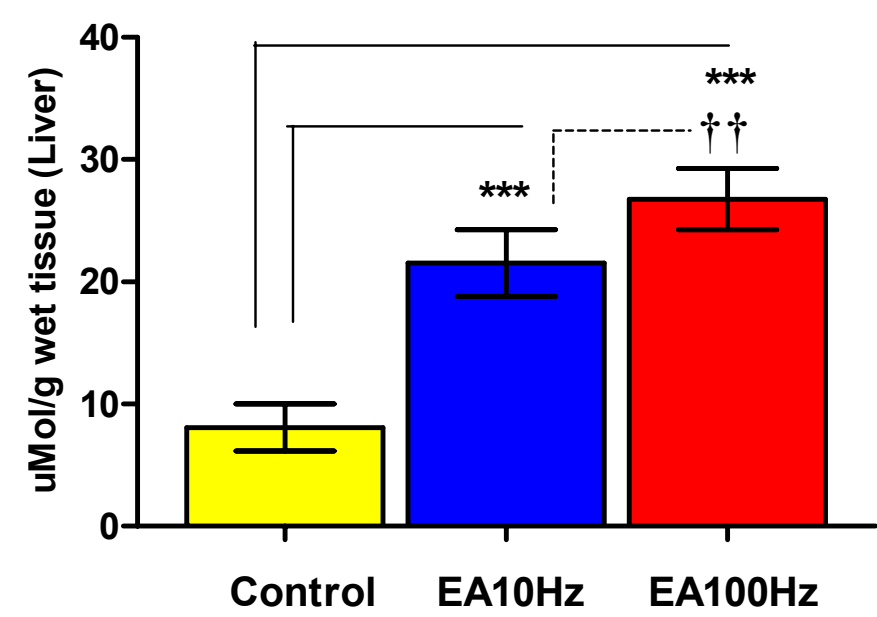

FIGURE 1 - Liver glutathione (GSH) levels sixty minutes after the start of the experiment. Bars represent mean \pm SD values for each group (Control, EA10Hz and EA100Hz). Samples were obtained from the left lobe of the liver of Control rats and EA-treated groups $(10$ and $100 \mathrm{~Hz})$ ( $n=6$, each group). GSH expressed as microMol/g of wet tissue. ANOVA/ Tukey tests.

$* * * \mathrm{p}<0.001$ compared with control; $\uparrow \uparrow \mathrm{p}<0.01$ compared with EA10Hz.

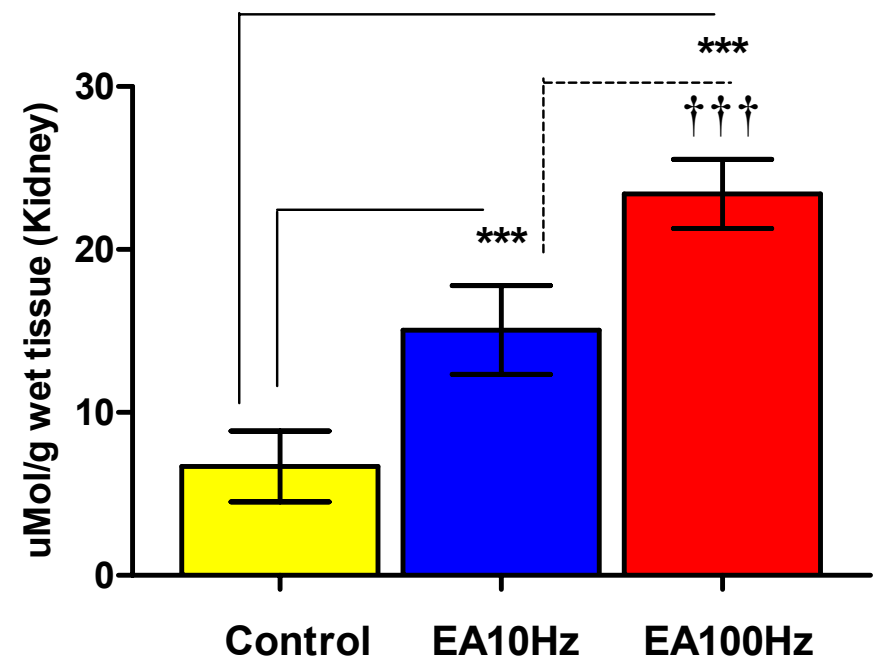

FIGURE 2 - Kidney glutathione (GSH) levels sixty minutes after the start of the experiment. Bars represent mean $\pm \mathrm{SD}$ values for each group (Control, EA10Hz and EA100Hz). Samples were obtained from the upper pole of the kidney of control rats and EA-treated groups $(10$ and $100 \mathrm{~Hz})$ ( $\mathrm{n}=6$, each group). GSH expressed as microMol/g of wet tissue. ANOVA/ Tukey tests.

$* * * \mathrm{p}<0.001$, compared with control; $\dagger \dagger \dagger \mathrm{p}<0.001$ compared with EA10Hz. 
MDA Assay

Liver MDA concentrations increased significantly in rats submitted to EA10Hz $(\mathrm{p}<0.01)$ and $\mathrm{EA} 100 \mathrm{~Hz}(\mathrm{p}<0.001)$, compared with control group (Figure 3). Similar increases in kidney MDA concentrations occurred in both $\mathrm{EA} 10 \mathrm{~Hz}$ and EA $100 \mathrm{~Hz}$ groups (Figure 4). Kidney MDA concentrations increased significantly in $\mathrm{EA} 100 \mathrm{~Hz}$ group compared with EA10Hz group.

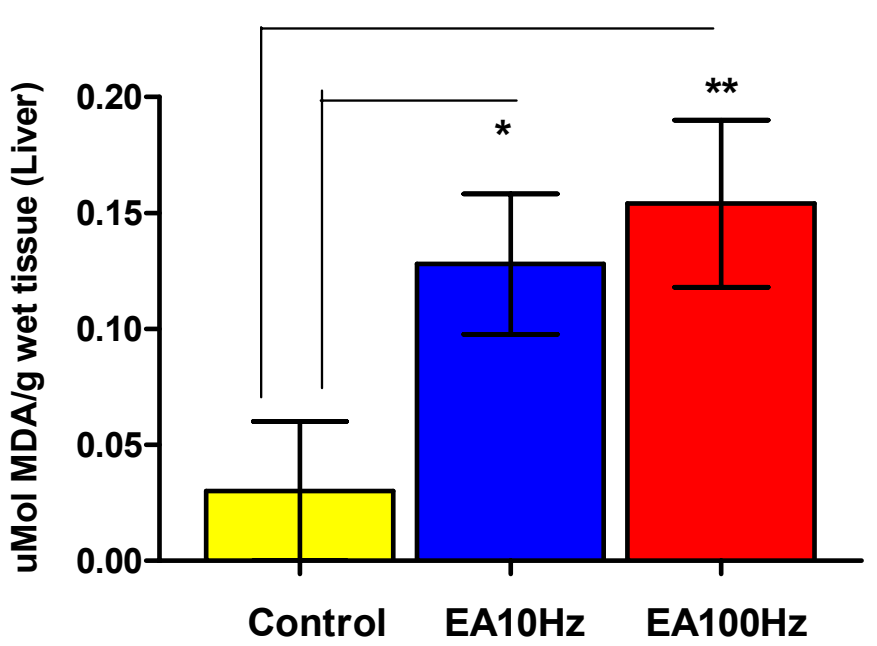

FIGURE 3 - Liver TBARS levels sixty minutes after the start of the experiment. Bars represent mean $\pm \mathrm{SD}$ values for each group (Control, $\mathrm{EA} 10 \mathrm{~Hz}$ and $\mathrm{EA} 100 \mathrm{~Hz}$ ). Samples were obtained from the left lobe of the liver of Control rats and EA-treated groups $(10$ and $100 \mathrm{~Hz})(\mathrm{n}=6$, each group). TBARS expressed as microMol/MDA/g of wet tissue. Kruskal-Wallis/Dunn tests.

$* * \mathrm{p}<0.01, * \mathrm{p}<0.05$ compared with control.

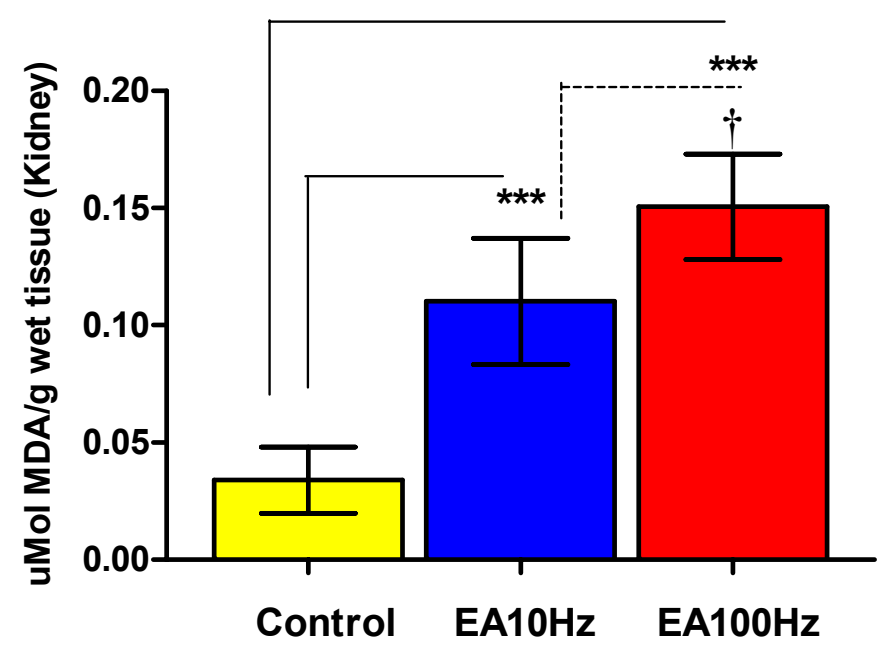

FIGURE 4 - Kidney TBARS levels sixty minutes after the start of the experiment. Bars represent mean $\pm \mathrm{SD}$ values for each group (Control, $\mathrm{EA} 10 \mathrm{~Hz}$ and $\mathrm{EA} 100 \mathrm{~Hz}$ ). Samples were obtained from the upper pole of the kidney of control rats and EA-treated groups $(10$ and $100 \mathrm{~Hz})(\mathrm{n}=6$, each group). TBARS expressed as microMol/MDA/g of wet tissue. Kruskal-Wallis/Dunn tests.

$* * * p<0.001$ compared with control; $\uparrow \mathrm{p}<0.05$ compared with EA10Hz.

\section{G6PDH Assay}

Liver G6GPH activity decreased significantly in EA100Hz groups $(\mathrm{p}<0.001)$ compared with control group (Figure 5). A similar pattern was found in kidney G6PDH activity in EA $10 \mathrm{~Hz}$ rats. Kidney G6PDH activity was not different in both groups (Figure 6).

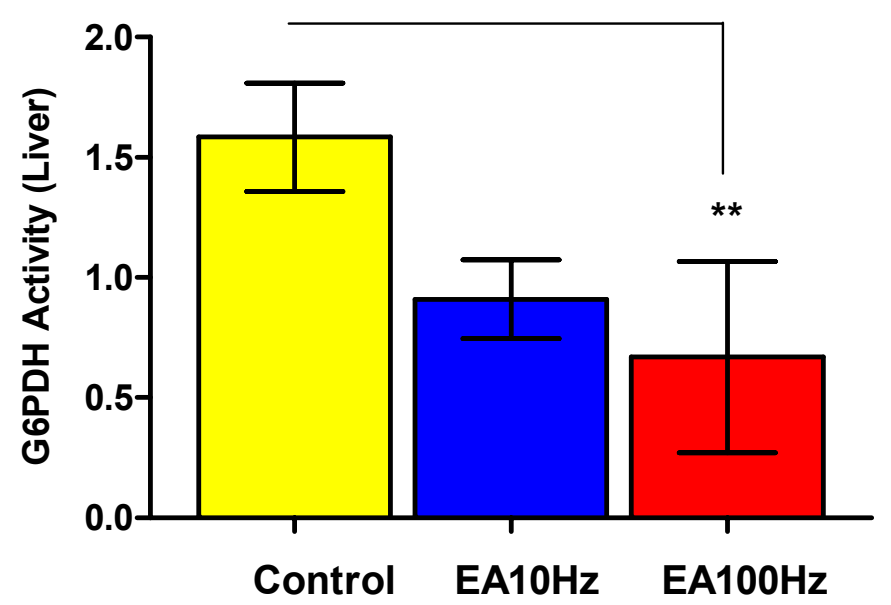

FIGURE 5 - Liver glucose-6-phosphate dehydrogenase (G6PDH) activity sixty minutes after the start of the experiment. Bars represent mean \pm SD values for each group (Control, EA $10 \mathrm{~Hz}$ and $\mathrm{EA} 100 \mathrm{~Hz}$ ). Samples were obtained from the left lobe of the liver of control rats and EA-treated groups (10 and $100 \mathrm{~Hz})(\mathrm{n}=6$, each group). G6PDH activity expressed as microMol/g of wet tissue. Kruskal-Wallis/Dunn tests.

$* * \mathrm{p}<0.01$, compared with control.

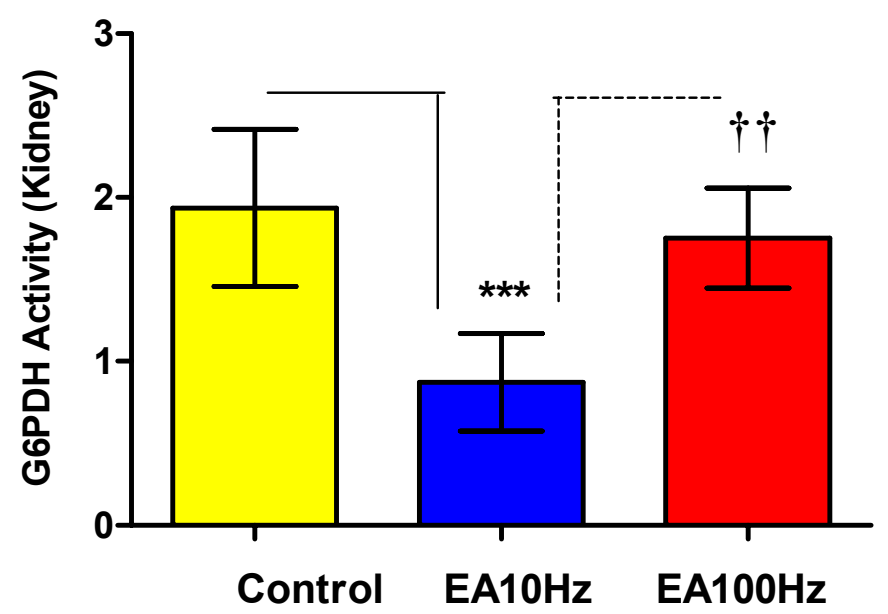

FIGURE 6 - Kidney glucose-6-phosphate dehydrogenase (G6PDH) activity sixty minutes after the start of the experiment. Bars represent mean \pm SD values for each group (Control, EA $10 \mathrm{~Hz}$ and EA $100 \mathrm{~Hz}$ ). Samples were obtained from the upper pole of the kidney of control rats and EA-treated groups (10 and $100 \mathrm{~Hz})(\mathrm{n}=6$, each group). G6PDH activity expressed as microMol/g of wet tissue. Kruskal-Wallis/Dunn tests. $* * * p<0.001$, compared with control; $\dagger p \mathrm{p}<0.01$ compared with EA10Hz. 


\section{Discussion}

In our experiment the oxidative stress was induced by the use of ketamine, a dissociative anesthetic agent, often used either during veterinary procedures or for experimental purposes. Alva et al. ${ }^{12}$ demonstrated that ketamine leads to increased plasmatic nitric oxide levels, induces metabolic acidosis, and causes oxidative damage, though without reaching hepatic toxicity.

Antiperoxidative effects of low frequency EA have been demonstrated. Siu et al. ${ }^{6}$ electro-stimulated the acupoints GB-20, located on the posterior aspect of the neck, below the occipital bone, in the depression between the sternocleidomastoid muscle and trapezius muscle and the ST-36, using multiple applications before cerebral ischemia and concluded that $2 \mathrm{~Hz}$ EA could partly regulate the lipid peroxidation in cerebral ischemia. GB-20 and ST-36 had a similar beneficial effectiveness ${ }^{6}$. In our study, the use of EA induced a significant raise in MDA concentration in the liver (Figure 3) and the kidney (Figure 4) in EA $10 \mathrm{~Hz}$ and EA $100 \mathrm{~Hz}$ groups. Additional increase in lipid peroxidation occurred in EA100Hz group compared with EA $10 \mathrm{~Hz}$ rats. This suggests that the kidney is more susceptible to lipid peroxidation than the liver. It seems that the use of electric stimulation utilizing high frequencies in a single session enhances the peroxidation of lipids in this rat model.

Yu et $a l . .^{22}$ evaluated the role of needle stimulation of four different acupoints: GB-34 (Yanglingquan), LR-3 (Taichong), ST-36 (Zusanli) and SP-10 (Xuehai) acupoints on regulating oxidative stress in the nigrostriatal system in the 6-hydroxydopamine lesioned rat and concluded that acupuncture stimulation prevented the reduction of GSH level as well as the increase in MDA level.

As we studied the effects of a single electroacupuncture session while in $\mathrm{Yu}$ et $a l .{ }^{22}$ evaluated the effects of the classic acupuncture treatment, performed twice a day for 14 days we believe that the use of electrical stimulation in a single session could be responsible for the increase in MDA levels. On the other hand, EA used in a single session induced a significant increase in GSH concentration in both liver (Figure 1) and kidney (Figure 2) tissues. The protective effect of EA is greater at higher frequencies as demonstrated by the increased concentration of GSH in the kidney of EA $100 \mathrm{~Hz}$ rats, compared to $\mathrm{EA} 10 \mathrm{~Hz}$ animals.

G6PDH plays a very important role in the cell response to the oxidative stress. Until recently there was a general belief that this enzyme importance was limited to human erythrocytes that lack any other NADPH producing route ${ }^{23}$. Recent observations have shown that the G6PDH plays a protective role against reactive oxygen species in eukaryotic cells that possess alternative routes for the production of $\mathrm{NADPH}^{24}$. In this study G6PDH activity decreased significantly in the liver of EA $10 \mathrm{~Hz}$ and EA $100 \mathrm{~Hz}$ groups. Similar fall in activity was seen in the kidney of EA $10 \mathrm{~Hz}$ rats. Kidney $\mathrm{GSH}$ concentrations increased in $\mathrm{EA} 100 \mathrm{~Hz}$ rats at the time a concomitant decrease in G6PDH was demonstrated in the same group.

Yu et al. ${ }^{25}$ have demonstrated that G6PDH activation is inversely correlated to GSH intracellular levels, utilizing cell suspension cultures of Taxus chinensis. It is possible that animal cells could have similar behavior.

As for strengths and weaknesses of this study in relation to others, there is no published study that can be directly compared with the present research. Despite the fact that peroxidative effects of EA were demonstrated here, in contrast with other studies ${ }^{6}, 10$ $\mathrm{Hz}$ electro stimulation was not used by other researchers. Published studies used low-frequency EA $(2 \mathrm{~Hz})$, in multiple sessions. In our study a single session was utilized. On the other hand the decrease in G6PDH activity in the liver and kidney of rats treated with $100 \mathrm{~Hz}$ and $10 \mathrm{~Hz}$, respectively, along with a concomitant increase in GSH levels, after a single EA session, suggest that higher frequencies could induce a better protection against oxidative stress. The mechanisms involved are not clear so far. Further studies may shed new light into the protective effects of electroacupuncture.

\section{Conclusion}

The data collected support the hypothesis that a single 30-minute EA $10 / 100 \mathrm{~Hz}$ session enhances lipid peroxidation and simultaneously reduces oxidative stress by increasing GSH levels in liver and kidney tissues in a rat model.

\section{References}

1. Campbell A. The origins of acupuncture. Acupunct Med. 2002;20(2-3):141

2. Zhou L, Chey WY. Electric acupuncture stimulates non-parietal cell secretion of the stomach in dog. Life Sci. 1984;34(23):2233-8

3. Li Y, Tougas G, Chiverton SG, Hunt RH. The effect of acupuncture on gastrointestinal function and disorders. Am J Gastroenterol. 1992;87(10):1372-81.

4. Lux G, Hagel J, Bäcker P, Bäcker G, Vogl R, Ruppin H, Domschke S, Domschke W. Acupuncture inhibits vagal gastric acid secretion stimulated by sham feeding in healthy subjects. Gut. 1994;35(8):1026-9.

5. Wu Y, Sun Z, Li Z, Zhao Y, Sun S. Effect of acupuncture on free radicals in rats with early experimental spinal cord injury. J Tradit Chin Med. 2002;22(1):51-4.

6. Siu FK, Lo SC, Leung MC. Effectiveness of multiple pre-ischemia electro-acupuncture on attenuating lipid peroxidation induced by cerebral ischemia in adult rats. Life Sci. 2004;75(11):1323-32.

7. Dai M, Ma XP, Shi Z, Wu HG, Zhao TP, Jiang GN. Effect of Acupuncture on Serum SOD and MDA of Rats in Menopause. J Acupunct Tuina Sci. 2008;6:79-82.

8. Wang XR, Xiao J, Sun DJ. Myocardial protective effects of electroacupuncture and hypothermia on porcine heart after ischemia/ reperfusion. Acupunct Electrother Res. 2003;28(3-4):193-200.

9. Chakrabarti AK, Chatterjee K, Ghosh JJ, Ganguly A. Electroacupuncture and its effect on rat hepatic functions. Acupunct Electrother Res. 1983;8(2):111-26.

10. Huang CL, Tsai PS, Wang TY, Yan LP, Xu HZ, Huang CJ. Acupuncture stimulation of ST36 (Zusanli) attenuates acute renal but not hepatic injury in lipopolysaccharide-stimulated rats. Anesth Analg. 2007;104(3):646-54.

11. Zhang Z, Apse K, Pang J, Stanton RC. High glucose inhibits glucose-6-phosphate dehydrogenase via cAMP in aortic endothelial cells. J Biol Chem. 2000;275(51):40042-7. 
12. Alva N, Palomeque J, Carbonell T. Nitric oxide induced by ketamine/ xylazine anesthesia maintains hepatic blood flow during hypothermia. Nitric Oxide. 2006;15(1):64-9.

13. Silva AH, Prado Neto AX, Guimarães SB. Electro-acupuncture reduces the need for additional anesthetics in experimental studies. Acta Cir Bras. 2010;25(4):381-4.

14. Lin JG, Chang SL, Cheng JT. Release of beta-endorphin from adrenal gland to lower plasma glucose by the electroacupuncture at Zhongwan acupoint in rats. Neurosci Lett. 2002;326(1):17-20.

15. Lin JG, Chen WC, Hsieh CL, Tsai CC, Cheng YW, Cheng JT, Chang SL. Multiple sources of endogenous opioid peptide involved in the hypoglycemic response to $15 \mathrm{~Hz}$ electroacupuncture at the Zhongwan acupoint in rats. Neurosci Lett. 2004;366(1):39-42.

16. World Health Organization (WHO). Standard Acupuncture Nomenclature: a brief explanation of 361 classical acupuncture points and their multilingual comparative list. 2ed. WHO Regional Office for the Western Pacific; 1993.

17. Liu CZ, Yu JC, Zhang XZ, Fu WW, Wang T, Han JX. Acupuncture prevents cognitive deficits and oxidative stress in cerebral multi-infarction rats. Neurosci Lett. 2006;393(1):45-50.

18. Yin CS, Jeong HS, Park HJ, Baik Y, Yoon MH, Choi CB, Koh HG. A proposed transpositional acupoint system in a mouse and rat model. Res Vet Sci. 2008;84(2):159-65.
19. Uchiyama M, Mihara M. Determination of malondialdehyde precursor in tissues by thiobarbituric acid test. Anal Biochem. 1978(1);86:271-8. 20. Sedlak J, Lindsay RH. Estimation of total, protein-bound, and nonprotein sulfhydryl groups in tissue with Ellman's reagent. Anal Biochem. 1968;25(1):192-205.

21. Bergmeyer HU, Gawehn K, Grassl M. Glucose-6-phosphate dehydrogenase. In: Bergmeyer HU (ed). Methods of enzymatic analysis. New York: Academic Press; 1974. p.458-9.

22. Yu YP, Ju WP, Li ZG, Wang DZ, Wang YC, Xie AM. Acupuncture inhibits oxidative stress and rotational behavior in 6-hydroxydopamine lesioned rat. Brain Res. 2010;1336:58-65.

23. Xu Y, Osborne BW, Stanton RC. Diabetes causes inhibition of glucose6-phosphate dehydrogenase via activation of PKA, which contributes to oxidative stress in rat kidney cortex. Am J Physiol Renal Physiol. 2005;289(5):F1040-7.

24. Salvemini F, Franzé A, Iervolino A, Filosa S, Salzano S, Ursini MV. Enhanced glutathione levels and oxidoresistance mediated by increased glucose-6-phosphate dehydrogenase expression. J Biol Chem. 1999;274(5):2750-7.

25. Yu LJ, Lan, WZ, Chen C, Yang Y. Glutathione levels control glucose6-phosphate dehydrogenase activity during elicitor-induced oxidative stress in cell suspension cultures of Taxus chinensis. Plant Sci. 2004;167:329-35.

\section{Correspondence:}

Sergio Botelho Guimarães

Rua Professor Costa Mendes, 1608/3 andar, Bloco Didático

60430-140 Fortaleza - CE Brasil

Tel.: (55 85)3366-8083

Fax: (55 85)3366-8064

sergiobotelho@terra.com.br

Conflict of interest: none

Financial source: none

${ }^{1}$ Research performed at Experimental Surgical Research Laboratory (LABCEX), Department of Surgery, Postgraduate Program, Federal University of Ceara (UFC), Brazil. 